\title{
Pendampingan Pendirian Dan Pengelolaan Koperasi Guna Membantu Permodalan Untuk Industri Rumahan Di Kelurahan Marga Mulya, Bekasi
}

\author{
Novita W Setyawati ${ }^{* 1}$, Dewi S Woelandari*2 ${ }^{* 2}$ Endah P Ningrum*3 \\ Universitas Bhayangkara Jakarta Raya, Bekasi
}

Korespondensi: novita.wahyu@dsn.ubharajaya.ac.id

Diserahkan: 14 Oktober 2018, Direvisi: 5 November 2018, Diterima: 20 Desember 2018

\begin{abstract}
Abstrak
Koperasi merupakan lembaga yang harus dikelola secara efektif dan efisien sebagaimana layaknya lembaga bisnis. Apabila koperasi mampu dikelola secara professional, maka bisa menjadi lembaga yang mampu memberi manfaat bagi anggotanya, terutama dalam hal bantuan permodalan usaha seperti pada koperasi yang berada di RT.005/RW.001, Kelurahan Marga Mulya, Kecamatan Bekasi Utara Kota Bekasi, yang merupakan lingkungan industry rumah tangga namun sering mengalami masalah pendanaan usaha, karena belum adanya lembaga keuangan yang mampu memenuhi kebutuhan permodalan warga. Kegiatan pengabdian kepada masyarakat (PKM) yang dilakukan tim penulis bertujuan untuk: 1) Mengedukasi tentang lembaga bisnis berbentuk koperasi, 2) Mengedukasi cara pendirian dan pengelolaan koperasi, 3) Pelatihan dan pendampingan guna peningkatan kualitas Sumber Daya Manusia (SDM) dan 4) Memberikan pendampingan mengenai pencatatan transaksi hingga laporan keuangan koperasi. Metode kegiatan berupa pelatihan dan pendampingan yang dilakukan secara intensif antara tim pelaksana dengan peserta, yatiu pengurus dan karyawan koperasi. Dari hasil kegiatan pendampingan dikatahui bahwa Perlu adanya pihak yang dapat menjembatani dalam pembentukan koperasi. Pendampingan dan pengawasan yang intensif terhadap koperasi tersebut juga perlu dilakukan.Selain itu, partisipasi warga juga diperlukan agar koperasi yang sudah terbentuk mampu berjalan dengan baik dan sehat.
\end{abstract}

Kata Kunci: Pelatihan, Pendampingan, Koperasi

\begin{abstract}
Cooperatives are institutions that must be managed effectively and efficiently as appropriate for business institutions. If cooperatives are able to be managed professionally, then it can be an institution that is able to provide benefits to its members, especially in terms of business capital assistance such as cooperatives in RT. 005 / RW. 001, Kelurahan Marga Mulya, Bekasi Utara District, Bekasi, which is household industry environment but often experience business funding problems, because there is no financial institution that is able to meet the capital needs of citizens. Community service activities (PKM) conducted by the author's team aimed to: 1) Educate about business institutions in the form of cooperatives, 2) Educate the way of establishing and managing cooperatives, 3) Training and mentoring to improve the quality of Human Resources (HR) and 4) Provide assistance regarding recording of transactions to cooperative financial statements. The method of activities is in the form of training and mentoring that is carried out intensively between the implementation team and the participants, orphans and employees of the cooperative. From the results of mentoring activities, it is known that there needs to be parties who can bridge the formation of cooperatives. Intensive assistance and supervision of the cooperative also needs to be done. In addition, citizen participation is also needed so that cooperatives that have been formed are able to run well and healthy.

Keywords: Training, Mentoring, Cooperatives
\end{abstract}

\section{A. PENDAHULUAN}

Secara harfiah kata koperasi berasal dari cooperation (latin), atau cooperation, atau co-operatie (belanda), dalam bahasa Indonesia diartikan sebagai bekerja bersama, atau bekerja sama, atau kerjasama, merupakan koperasi.Berdasarkan Undang-Undang Nomor 25 Tahun 1992 tentang perkoperasian bahwa pengertian koperasi adalah badan usaha yang beranggotakan orang-orang atau badan hukum koperasi dengan melandaskan kegiatannya 
berdasarkan prinsip koperasi sekaligus sebagai gerakan ekonomi rakyat yang berdasarkan atas asas kekeluargaan.

Tujuan utama pendirian suatu koperasi adalah menciptakan kesejahteraan para anggotanya. Ini dapat dicapai dengan menyediakan barang dan jasa yang mereka butuhkan dengan harga murah, menyediakan fasilitas produksi atau menyediakan dana untuk pinjaman dengan bunga yang sangat rendah. Hal ini bertujuan untuk meningkatkan kesejahteraan anggota pada khususnya dan masyarakat pada umumnya dan ikut serta membangun tatanan perekonomian nasional dalam rangka mewuj udkan masyarakat yang maju, adil dan makmur berlandaskan Pancasila dan Undang-Undang dasar 1945.

Untuk melancarkan jalannya roda perekonomian inilah sangat dibutuhkan sebuah lembaga, salah satunya koperasi. Koperasi merupakan lembaga yang harus dikelola sebagaimana layaknya lembaga bisnis, karena jika hal ini dilakukan secara professional, akan mendatangkan manfaat yang luar biasa, khususnya bagi anggotanya (Mutiarni, R., Utomo, L. P., \& Zuhroh, S, 2017). Di dalam sebuah lembaga bisnis diperlukan sebuah pengelolaan yang efektif dan efisien. Sebagai organisasi bisnis, koperasi harus taat pada pengelolaan yang sehat, transparan, terpertanggung jawab, dan bersikap adil dalam pencapaian tujuan bersama. Terlebih lagi, koperasi harus mampu menyediakan pinjaman modal, mampu menyediakan kebutuhan anggotanya, serta dapat membantu memasarkan hasil dari usaha anggotanya dengan harga yang layak.

Jenis organisasi berupa koperasi sesuai dengan kebutuhan masyarakat yang membutuhkan pendanaan untuk usaha mikro, secara cepat, aman, tidak membutuhkan jaminan serta administrasi yang ruwet. Hal ini pula yang menurut pengamatan awal tim penulis, cocok dan layak untuk diterapkan di lingkungan masyarakat RT. 005/RW.001, Kelurahan Marga Mulya, Kecamatan Bekasi Utara Kota Bekasi.

\section{B. PROFIL MITRA}

Masyarakat di RT. 005/RW.001, Kelurahan Marga Mulya, Kecamatan Bekasi Utara Kota Bekasi adalah kelompok usaha industri rumahan (home industry) akan tetapi mengalami permasalahan berupa permodalan usaha atau kesulitan dalam hal perputaran keuangan usaha. Selama ini mereka hanya mengembangkan modal usaha seadanya. Masyarakat memerlukan bantuan permodalan yang bisa diakses secara cepat, aman, dan tidak membebani untuk masalah bunga dan jangka waktu pengembalian, serta tidak diribukan masalah administrasi dan jaminan. Maka jawaban dari masalah ini adalah koperasi.

Berdasarkan kondisi dan permasalahan tersebut, maka perlu diadakannya pendampingan penguatan organisasi melalui pendirian dan pengelolaan koperasi di RT.005/RW.001, Kelurahan Marga Mulya, Kecamatan Bekasi Utara Kota Bekasi. Selanjutnya, tim penulis beserta warga sekitar sepakat untuk mendirikan koperasi dengan bentuk usaha simpan pinjam bagi warga di wilayah RT.005/RW.001, Kelurahan Marga Mulya, Kecamatan Bekasi Utara Kota Bekasi.

\section{METODE PELAKSANAAN}

Sebelum menentukan kegiatan yang sesuai dengan kebutuhan mitra, tim penulis melakukan koordinasi antar anggotakan persepsi. Dari hasil koordinasi awal, maka diputuskan rangkaian kegiatan ini adalah:

Koordinasi awal untuk menyamakan persepsi dan rencana tindak lanjut

1. Melakukan observasi terhadap mitra binaan. Hal ini meliputi: 1) Pemetaan kondisi masyarakat di RT.005/RW.001, Kelurahan Marga Mulya, Kecamatan Bekasi Utara Kota Bekasi, 2) Kebutuhan masyarakat terkait dengan lembaga pendanaan untuk kegiatan industri rumahan (home industry). 
2. Melakukan wawancara mendalam (indepth interview) dan konseling yang dikenal dengan metode Participatory Rural Apraisal (PRA). Metode ini digunakan untuk meningkatkan partisipasi masyarakat terutama dalam menyusun kebutuhan atau program, disamping itu konsultan juga akan melakukan pendekatan dengan metode Focus Discussion Group $(F G D)$, untuk mendorong terbangunnya kebersamaan anggota masyarakat atau kelompok masyarakat . Kegiatan ini melibatkan tokoh masyarakat dan warga masyarakat untuk mengetahui dan mendapatkan informasi secara lebih dalam dan akurat. Dari hasil wawancara mendalam, maka diketahui bahwa masyarakat di RT.005/RW.001, Kelurahan Marga Mulya, Kecamatan Bekasi Utara Kota Bekasi khusunya para pemilik usaha industri rumahan membutuhkan lembaga keungan yang bisa membantu memberikan solusi keuangan mikro secara cepat, aman, fleksibel, tidak repot administrasi dan tanpa agunan/jaminan. Maka dari hasil wawancara mendalam, serta konseling untuk menggali masalah dan potensi yang dimiliki, membuka alternative alternatif solusi dan mendorong masyarakat untuk mengambil keputusan berdasarkan pertimbangan bertanggungjawab, diputuskanlah tentang pembentukan lembaga/organisasi keuangan dengan bentuk koperasi.

3. Selanjutnya, dari hasil keputusan bersama tentang pembentukan koperasi, tim penulis melakukan pelatihan dan pendampingan untuk pembentukan koperasi.

Kegiatan ini meliputi:

a. Pembentukan perangkat koperasi, meliputi pengurus, pengawas dan karyawan koperasi serta merekrut anggota koperasi untuk mengumpulkan modal awal.

b. Pembentukan dan pembuatan Anggaran Dasar (AD) dan Anggaran Rumah Tangga (ART). Untuk memudahkan sosialisasi, tim membuatnya dalam bentuk buku saku.

c. Guna meningkatkan kemampuan Sumber Daya Manusia (SDM), tim penulis memberikan pelatihan kepada karyawan dan pengurus koperasi, tentang tata cara pengelolaan koperasi, pencatatan transaksi hingga penyusunan laporan keuangan.

\begin{tabular}{|c|c|c|}
\hline $\begin{array}{l}\text { Perencanaan } \\
\text { 1. Koordinasi tim } \\
\text { pelaksana } \\
\text { 2. Pemetaan dan } \\
\text { observasi awal } \\
\text { kondisi mitra }\end{array}$ & $\begin{array}{l}\text { Proses Kegiatan } \\
\text { 1. Observasi lapangan } \\
\text { 2. Indepth interview, } \\
\text { konseling dan PRA } \\
\text { 3. Pelatihan \& } \\
\text { pendampingan untuk: } \\
\text { a. Pembentukan } \\
\text { perangkat koperasi } \\
\text { b. Penyusunan } \\
\text { AD/ART } \\
\text { c. Pelatihan dan } \\
\text { Pendampingan untuk } \\
\text { pengelolaan koperasi }\end{array}$ & \begin{tabular}{l}
\multicolumn{1}{c}{ Hasil } \\
1. Terbentuknya \\
Koperasi \\
2. Terbantunya \\
permodalan usaha \\
masyarakat \\
3. Buku saku tentang \\
Koperasi \\
4. Terlaksananya \\
Kegiatan pengabdian \\
kepada masyarakat.
\end{tabular} \\
\hline
\end{tabular}

Gambar 1: Rangkaian Kegiatan

\section{HASIL KEGIATAN}

Berdasarkan rencana kerja dan pelaksanaan kegiatan pengabdian kepada masyarakat berupa Pendampingan dan pelatihan untuk pengelolaan Koperasi di RT.005/ RW.001, Kelurahan Marga Mulya, Kecamatan Bekasi Utara Kota Bekasi, diperoleh hasil yang memuaskan. Kegiatan ini adalah permulaan sehingga diharapkan kegiatan ini bisa ditindaklanjuti. 
Adapun target pasca pendampingan pengabdian kepada masyarakat diharapkan sebagai berikut :

a. Dapat membantu penguatan pengelolaan koperasi.

b. Dapat membantu pencatatan transaksi hingga penyusunan laporan keuangan di koperasi.

c. Dapat membantu memberikan pengarahan mengenai tertib administrasi koperasi.

\section{E. PENUTUP}

Program pendampingan ini dapat diselenggarakan dengan baik dan berjalan dengan lancar sesuai dengan rencana kegiatan yang telah disusun. Namun demikian, kegiatan ini masih merupakan tahap awal, sehingga diperlukan pembinaan lebih lanjut khususnya untuk tenaga koperasi yang akan mengelola didalamnya, yang sangat membutuhkan komitmen untuk pengelolaannya. Kegiatan ini mendapat sambutan yang sangat baik terbukti dengan keaktifan dan antusiatisme peserta dalam keingintahuan dalam membentuk dan mengelola koperasi sesuai dengan tuntunan narasumber terkait. Diharapkan, kegiatan ini bisa diteruskan oleh semua pihak yang tertarik untuk melakukan pembinaan tentang koperasi, baik dari perguruan tinggi maupun pemerintah melalui Dinas Koperasi. Sehingga, tujuan akhir dari koperasi di RT.005/ RW.001, Kelurahan Marga Mulya, Kecamatan Bekasi Utara Kota Bekasi yaitu memberikan bantuan permodalan mikro untuk masyarakat pada umumnya dan pelaku I industi rumahan (home industry) dapat terwujud.

\section{DAFTAR PUSTAKA}

Baswir,Revisond. 2013. ”Koperasi Indonesia Edisi Kedua”. Yogyakarta: BPFE.

Mutiarni, R., Utomo, L. P., \& Zuhroh, S. (2017). Pendampingan Pencatatan Transaksi Keuangan Pada Koperasi Bunga Harapan Desa Ceweng. Comvice: Journal Of Community Service, 1(1), 33-38.

Widiyati, N. 2010. Manajemen Koperasi. Jakarta. PT Asdi Mahasatya.

Subandi. 2011. "Ekonomi Koperasi (Teori dan Praktek)”. Bandung: ALFABETA.

Yustika,Erani. 2012. "Ekonomi Kelembagaan Paradigma,Teori, dan Kebijakan". Jakarta: Erlangga.

Undang-undang Republik Indonesia no 17 tahun 2012 Tentang Perkoperasian 